\title{
導電性薄膜を伝熱面とした対流熱伝達測定の 周波数応答および空間分解能*
}

\author{
中 村 \\ 元*1

\section{Frequency-Response and Space-Resolution for Measurements of Convective Heat Transfer Using a Thin Conductive Film}

\author{
Hajime NAKAMURA*2 \\ *2 Department of Mechanical Engineering, National Defense Academy, \\ 1-10-2 Hashirimizu, Yokosuka-shi, Kanagawa, 239-8686 Japan
}

\begin{abstract}
A technique for measurements of time-space distribution of convective heat transfer has been developed using a test surface fabricated from a thin conductive film heated electrically. The fluctuating temperature on the test surface can be measured using infrared thermograph having high frame-rate, if the heat capacity of the test surface is sufficiently low. In this work, the frequencyresponse of the heat transfer from the test surface was investigated by solving the heat conduction equations by considering the heat losses. Also, the spatial resolution due to the lateral conduction through the test surface was investigated. The upper limit of the fluctuating frequency and the lower limit of the spatial wavelength, which is detectable using infrared thermography, are found to be uniquely decided for each test surface as a function of $\left(\bar{T}_{w}-T_{0}\right) \Delta h / \Delta T_{I R 0}$, where $\left(\bar{T}_{w}-T_{0}\right)$ is the mean temperature difference between the wall and freestream, $\Delta h$ is time or spatial amplitude of the heat transfer coefficient, and $\Delta T_{I R 0}$ is a temperature difference equivalent to noise of infrared measurements for the black body.
\end{abstract}

Key Words : Forced Convection, Heat Transfer, Turbulent Flow, Frequency Response, Space Resolution, Conductive Film, Infrared Thermography

\section{1. ま え がき}

一般に, 対流熱伝達には非定常性および非一様性が 存在する.しかし, 熱伝達の実験的研究では, ほとん どの場合において時間平均的な測定や点計測しかなさ れておらず, 熱伝達の時空間的挙動に関する理解が不 十分である場合が多い.

そこで, 感温液晶や赤外線カメラを用いて伝熱面の 温度変動を測定し, 熱伝達の時空間特性を調べる試み がいくつかなされてきた(1) (6). しかし, この手法の最 大の問題点は, 伝熱面の熱容量の影響で時間的な減 衰・遅れが発生することである.さらに, 伝熱面に温 度分布があると熱伝導が発生し, それが空間的な減衰 をもたらす。そのため, 上記の手法を用いて熱伝達の 時空間的な挙動を調べるためには, 時間的・空間的減 衰の程度を把握するのが不可欠となるばかりでなく, 正確な熱伝達率を求めるためには, 時空間的な減衰を 復元する必要がある。

本報では, 赤外線カメラを用いて対流熱伝達の時空

\footnotetext{
* 原稿受付 2006 年 3 月 20 日.

*1 正員, 防衛大学校機械工学科 (者 239-8686 横須賀市走水 110-20).

E-mail : nhajime@nda.ac.jp
}

間特性を測定することを想定し, 伝熱面からの熱伝達 の周波数応答および空間分解能について解析的に調べ た。また, 赤外線カメラで測定可能な周波数の上限お よび空間波長の下限を解析的に導出した.

\section{記 号}

$b$ : 空間分布の波長 $\mathrm{m}$

$c:$ 比熱 $\mathrm{J} /(\mathrm{kg} \cdot \mathrm{K})$

$f, f_{c}$ : 周波数, カットオフ周波数 $\mathrm{Hz}$

$h:$ 対流熱伝達率 $\mathrm{W} /\left(\mathrm{m}^{2} \cdot \mathrm{K}\right)$

$h_{t}$ : 熱伝導, 熱放射を含めた全熱伝達率

$$
\mathrm{W} /\left(\mathrm{m}^{2} \cdot \mathrm{K}\right)
$$

$k:=\sqrt{\omega / 2 \alpha} \mathrm{m}^{-1}$

$\dot{q}:$ 熱流束 $\mathrm{W} / \mathrm{m}^{2}$

$T:$ 温度 $\mathrm{K}$

$T_{0}, T_{w}$ : 主流温度, 壁面温度 $\mathrm{K}$

$\Delta T_{I R}$ : 赤外線計測の雑音等価温度差 $\mathrm{K}$

$\Delta T_{I R 0}$ : 赤外線計測の雑音等価温度差 (黑体) $\mathrm{K}$

$t$ : 時間 $\mathrm{s}$

$x, y$ : 面方向, 垂直方向

$\alpha$ : 温度伝導率 $=\lambda / c \rho \quad \mathrm{m}^{2} / \mathrm{s}$

$\beta$ : 空間分解能 $\mathrm{m}$ 
$\delta:$ 厚さ $\mathrm{m}$

$\varepsilon_{t}:$ 全放射率

$\varepsilon_{I R}:$ 赤外線測定波長帯域の分光放射率

$\phi:$ 位相遅れ

$\eta:$ 時間変動振幅の減衰率

$\lambda:$ 熱伝導率 $\mathrm{W} /(\mathrm{m} \cdot \mathrm{K})$

$\nu:$ 流体の動粘性係数 $\mathrm{m}^{2} / \mathrm{s}$

$\rho:$ 密度 $\mathrm{kg} / \mathrm{m}^{3}$

$\tau$ : 時定数 $\mathrm{s}$

$\omega$ : 角周波数 $=2 \pi f \mathrm{rad} / \mathrm{s}$

$\xi$ : 空間分布振幅の減衰率

添字

$a, c, p$ : 空気層, 伝導板, 平板

$c d, c v, r d$ : 伝導, 対流, 放射

$f, s$ : 周波数特性, 空間特性

$r$ : 平板上面 (測定面と対向した面)

表記法

$\left(^{-}\right)$: 平均値

( ) : 無次元数

( )*: 実効值

\section{2. 解 析 方 法}

$2 \cdot 1$ 平板モデル 赤外線カメラを用いて空気へ の対流熱伝達の時空間分布を測定することを想定し， 図 1 のような平板モデルを考案した。平板の周囲では 空気が上下対称に流れている．平板(厚さ $\delta_{p}$ )の測定 部は空洞になっており, その上下面に導電性薄膜(比 熱 $c$, 密度 $\rho$, 厚さ $\delta$, 熱伝導率 $\lambda$, 全放射率 $\left.\varepsilon_{t}\right)$ が接 着されている，また，両薄膜の間には空気層(厚さ $\delta_{a}$, 比熱 $c_{a}$, 密度 $\rho_{a}$, 熱伝導率 $\left.\lambda_{a}\right)$ を挟んで, 熱伝導率の 高い伝導板（厚さ $\delta_{c}$, 比熱 $c_{c}$, 密度 $\rho_{c}$, 熱伝導率 $\lambda_{c}$, 全放射率 $\left.\varepsilon_{t c}\right)$ が設置されている. 薄膜は熱流束一定の 条件で通電加熱される。なお，本解析で用いた寸法で は薄膜と伝導板に挟まれた空気層内のレイリー数は十 分低く，空気の流動は起こらない.

$2 \cdot 2$ 基礎方程式 解析領域を図 2 に示す. $x$ 座 標を平板の面方向に, $y$ 座標を厚さ方向にとる.上下 の薄膜では以下のエネルギーバランスが成り立つ.

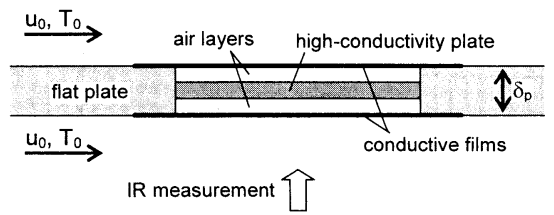

Fig. 1 Flat plate for measurements of time-space distribution of heat transfer coefficient

$$
\begin{aligned}
& c \rho \delta \frac{\partial T_{w}}{\partial t}=\lambda \delta \frac{\partial^{2} T_{w}}{\partial x^{2}}+\dot{q},(y=0) \cdots \cdots \cdots \\
& c \rho \delta \frac{\partial T_{w r}}{\partial t}=\lambda \delta \frac{\partial^{2} T_{w r}}{\partial x^{2}}+\dot{q}_{r},\left(y=\delta_{p}\right) \cdots
\end{aligned}
$$

$T_{w}, T_{w r}$ は，それぞれ下側薄膜(測定面)，上側薄膜の 温度である. なお, 薄膜は十分薄く, 厚さ方向に温度 が一様であるとする.また $\dot{q}, \dot{q} r$ は薄膜に与えられ る熱流束であり，それぞれ次式で表される。

$$
\begin{aligned}
& \dot{q}=\dot{q}_{i n}-\dot{q}_{c v}-\dot{q}_{c d}-\dot{q}_{r d}-\dot{q}_{r d i} \cdots \cdots \cdots \cdots(2 \cdot \mathrm{a}) \\
& \dot{q}_{r}=\dot{q}_{i n}-\dot{q}_{c v r}-\dot{q}_{c d r}-\dot{q}_{r d r}-\dot{q}_{r d i r} \cdots \cdots(2 \cdot \mathrm{b})
\end{aligned}
$$

$\dot{q}_{i n}$ は通電加熱により与えられる熱流束, $\dot{q}_{c v}$ は薄膜 表面から外部空気への対流熱流束， $\dot{q}_{c d}$ は薄膜裏面か ら空気層への伝導熱流束, $\dot{q}_{r d}$ は薄膜表面から外部へ の放射熱流束， $\dot{q} r d i$ は薄膜裏面から伝導板への放射熱 流束である．添字の $r$ は，上側の薄膜の值を示してい る。なお，各熱流束の值は次式で表される。

$$
\begin{aligned}
& \dot{q}_{\text {in }}=\frac{I E}{A} \\
& \dot{q}_{c v}=h\left(T_{w}-T_{0}\right), \quad \dot{q}_{c v r}=h_{r}\left(T_{w r}-T_{0}\right) \\
& \dot{q}_{c d}=-\lambda_{a}\left(\frac{d T}{d y}\right)_{y=0+}, \quad \dot{q}_{c d r}=\lambda_{a}\left(\frac{d T}{d y}\right)_{y=\delta p-} \\
& \dot{q}_{r d i}=\frac{\sigma\left(T_{w}^{4}-T_{c}^{4}\right)}{1 / \varepsilon_{t}+1 / \varepsilon_{t c}-1}, \quad \dot{q}_{r d i r}=\frac{\sigma\left(T_{w r}^{4}-T_{c r}^{4}\right)}{1 / \varepsilon_{t}+1 / \varepsilon_{t c}-1}
\end{aligned}
$$

ここで, $I, E$ は薄膜に与える電流, 電圧, $A$ は伝熱面 の面積である．また， $h$ は対流熱伝達率， $T_{0}$ は主流温 度であり， $T_{c}$ は伝導板の表面温度，。はステファン・ ボルツマン定数である.

また，空気層内抢よび伝導板内では，それぞれ以下 の熱伝導方程式が成り立つ.

$$
\begin{aligned}
c_{a} \rho_{a} \frac{\partial T}{\partial t} & =\lambda_{a}\left(\frac{\partial^{2} T}{\partial x^{2}}+\frac{\partial^{2} T}{\partial y^{2}}\right), \\
(0<y & \left.<\delta_{a}, \delta_{p}-\delta_{a}<y<\delta_{p}\right) \cdots \cdots \cdots \cdots \cdots(8 \cdot \mathrm{a}) \\
c_{c} \rho_{c} \frac{\partial T}{\partial t} & =\lambda_{c}\left(\frac{\partial^{2} T}{\partial x^{2}}+\frac{\partial^{2} T}{\partial y^{2}}\right),\left(\delta_{a}<y<\delta_{p}-\delta_{a}\right)
\end{aligned}
$$

また，空気層と伝導板の境界では次式が成り立つ。

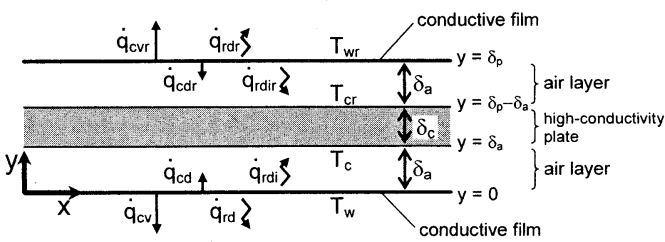

Fig. 2 Calculation region for heat conduction analysis 


$$
\begin{aligned}
& \lambda_{a}\left(\frac{\partial T}{\partial y}\right)_{y=\delta_{a-}}=\lambda_{c}\left(\frac{\partial T}{\partial y}\right)_{y=\delta_{a+}} \\
& \lambda_{c}\left(\frac{\partial T}{\partial y}\right)_{y=\left(\delta_{p}-\delta_{a}\right)-}=\lambda_{a}\left(\frac{\partial T}{\partial y}\right)_{y=(\delta p-\delta a)+}
\end{aligned}
$$

式 (1)〜（9)を差分法で解き，伝熱面の周波数応答お よび空間分解能を求めた。

\section{3. 周 波 数 応 答}

$3 \cdot 1$ 時定数の解析解 はじめに, 熱伝導, 熱放射 が十分小さい場合の解析解を求める. 温度測定面(下 側の薄膜)では, 式 $(1 \cdot a) ，(2 \cdot a) ，(4)$ より次式が成り 立つ.

$$
c \rho \delta \frac{\partial T_{w}}{\partial t}=\dot{q}_{i n}-h\left(T_{w}-T_{0}\right)
$$

このとき, 表面温度 $T_{w}$ の時定数 $\tau$ は次のように定義 される。

$$
\tau=\frac{c \rho \delta}{h}
$$

$3 \cdot 2$ 熱損失を考慮した周波数応答 次に, 熱伝 導, 熱放射を考慮した数值解析を行う。ここでは, 薄 膜表面 $(y=0)$ の温度が一様であり, 熱伝達率が次式の ように正弦的に変動する場合を考える.

$$
h=\bar{h}+\Delta h \sin (\omega t)
$$

この熱伝達率変動を実験的に評価しようとすれば, 簡 単には薄膜表面の温度変動 $T_{w}$ および伝導板の時間平 均温度 $\bar{T}_{c}$ を測定すればよく, このとき, 熱伝達率 $h_{f 1}$ は次式で評価することができる.

$$
\begin{aligned}
& h_{f 1}=\frac{\dot{q}_{i n}-\dot{q}_{c d}^{\prime}-\dot{q}_{r d}-\dot{q}_{r d i}^{\prime}}{T_{w}-T_{0}} \\
& \dot{q}_{c d}^{\prime}=\lambda_{a} \frac{T_{w}-\bar{T}_{c}}{\delta_{a}} \cdots \ldots \ldots \ldots . . . \\
& \dot{q}_{r d i}^{\prime}=\frac{\sigma\left(T_{w}^{4}-\bar{T}_{c}^{4}\right)}{1 / \varepsilon_{t}+1 / \varepsilon_{t c}-1} \cdots \cdots . . .
\end{aligned}
$$

$\dot{q}_{c d}^{\prime}$ は, 空気層内の温度分布が線形であると仮定した 場合の伝導熱流束であり, $k_{a} \delta_{a}<1$ であれば誤差が小 さい (5・1 節参照)。また, 赤外線計測のフレーム間陾 が十分小さければ，薄膜の熱容量に起因する時間遅れ を次式のように補正することができる。

$$
h_{f 2}=\frac{\dot{q}_{i n}-\dot{q}_{c d}^{\prime}-\dot{q}_{r d}-\dot{q}_{r d i}^{\prime}-c \rho \delta \frac{d T_{w}}{d t}}{T_{w}-T_{0}}
$$

式(13)および式(16)から評価される熱伝達率 $h_{f 1}$, $h_{f 2}$ と式(12) で与えた真の熱伝達率 $h$ の差異を, 非定 常一次元解析により調べた。図 3 に, 熱伝達率の変動 波形の一例 (チタンはく, $\delta=2 \mu \mathrm{m}, \bar{h}=30 \mathrm{~W} /\left(\mathrm{m}^{2} \cdot \mathrm{K}\right)$, $f=2 \mathrm{~Hz})$ を示す. $h_{f 1}$ の振幅は大きく減衰しており位 相遅れも大きいが, 薄膜の熱容量の影響を補正した $h_{f 2}$ は, 減衰・位相遅れともに抑えられ, 真の值 $h$ に

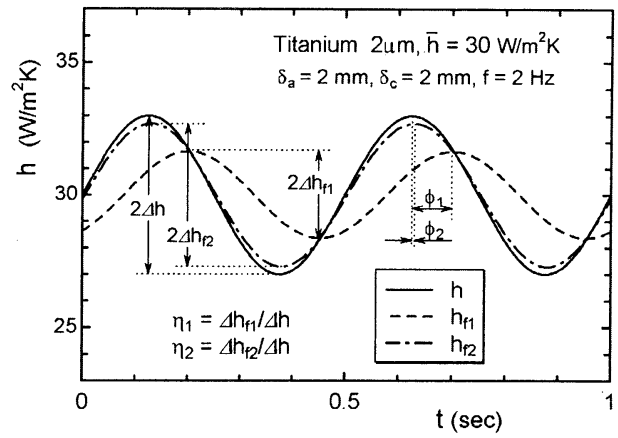

Fig. 3 Time trace of an original and estimated heat transfer coefficients; Ti foil, $\delta=2 \mu \mathrm{m}, \bar{h}=30$ $\mathrm{W} /\left(\mathrm{m}^{2} \cdot \mathrm{K}\right), f=2 \mathrm{~Hz}$

近づいている.ここで, 振幅の減衰率を $\eta\left(\eta_{1}=\right.$ $\left.\Delta h_{f 1} / \Delta h, \eta_{2}=\Delta h_{f 2} / \Delta h\right)$, 位相遅れを $\phi\left(\phi_{1}, \phi_{2}\right)$ と定義 する。

図 4 に, チタンはく $\left[\delta=2,0.2 \mu \mathrm{m}, c \rho=2.35 \times 10^{6}\right.$ $\mathrm{J} /\left(\mathrm{m}^{3} \cdot \mathrm{K}\right)$ ] を用いた場合の周波数特性を示す. 図 4( a ) が振幅の減衰率 $\eta$, 図 4(b) が位相遅れ $\phi$ であ る. 伝導板は厚さ $\delta_{c}=2 \mathrm{~mm}$ の銅板とし, 空気層の厚 さは $\delta_{a}=1,2 \mathrm{~mm}$ とした。また，その他の条件は平 板乱流境界層の測定 ${ }^{(7)}$ を想定した值 $($ 時間平均熱伝達 率 $\bar{h}=30 \mathrm{~W} /\left(\mathrm{m}^{2} \cdot \mathrm{K}\right)$, 変動幅 $\Delta h=0.1 \bar{h}$, 伝熱面温度 $T_{w}=50^{\circ} \mathrm{C}$, 主流温度 $\left.T_{0}=20^{\circ} \mathrm{C}\right)$ とした。

図 4(a)，（b )より，式(13)で見積もられた熱伝達 率 $h_{f 1}$ は周波数の上昇とともに大きく減衰し(減衰率 $\eta_{1}$ が小さくなり)，位相遅れ $\phi_{1}$ も大きくなる．また， 減衰・位相遅れは, 熱容量 $c \rho \delta$ の低下とともに高周波 数側にシフトする.さらに, 空気層が厚いほど減衰・ 位相遅れが大きくなる。これは後述 $(5 \cdot 1$ 節) のように, 空気層内の一部の空気が薄膜とともに温度変動し, 伝 熱面の実効的な熱容量が増加するためである．薄膜の 熱容量 $c \rho \delta$ が小さいほどこの影響が大きくなる。一 方，薄膜の熱容量を補正した場合 $\left(\eta_{2}, \phi_{2}\right)$ は高周波数 側での減衰，位相遅れが抑えられている．ただし，薄 膜とともに空気層の温度も変動するため, 式(16)のよ うに薄膜の熱容量の影響を補正しただけでは完全に熱 伝達率の変動を復元できない. 完全には復元するため には，空気層まで含めた非定常熱伝導の逆問題を解く 必要がある。

図 4( c ) に, 伝熱面の温度変動振幅 $\Delta T_{w}$ を示す. この值が赤外線計測の雑音等価温度差よりも大きけれ ば温度変動を検知することができ, 本測定が可能とな る.変動の周波数が低い場合は, 空気層厚さ $\delta_{a}$ が大 


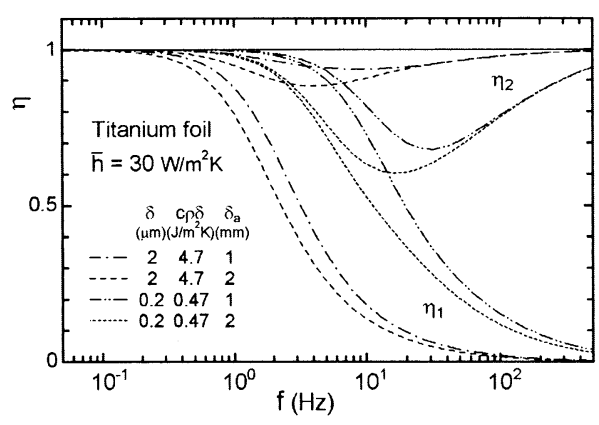

(a) attenuation rate of fluctuating amplitude, $\eta$

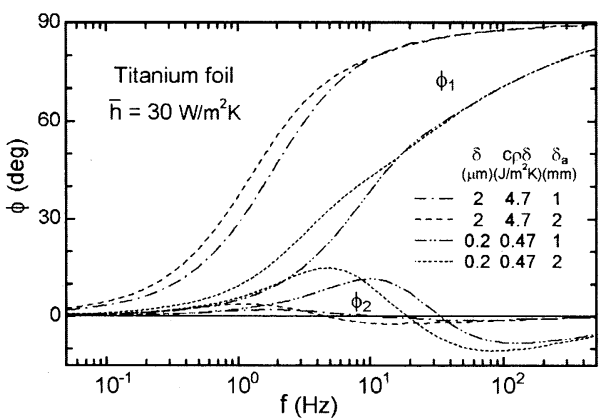

(b) phase delay, $\phi$

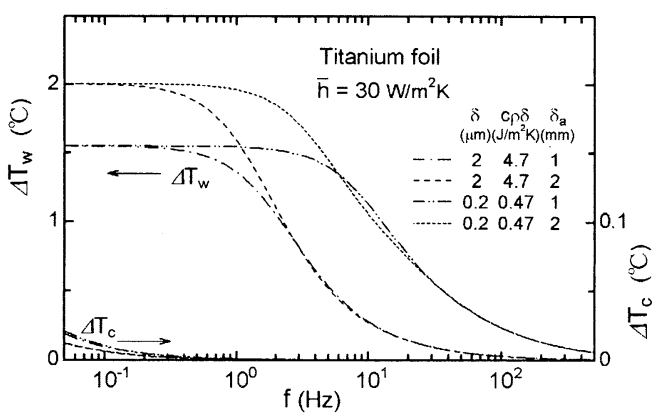

(c) amplitude of fluctuating temperature; $\Delta T_{w}$ and $\Delta T_{c}$

Fig. 4 Frequency response; Ti foil, $\delta=2 \mu \mathrm{m}, \bar{h}=30$ $\mathrm{W} /\left(\mathrm{m}^{2} \cdot \mathrm{K}\right)$

きいほど断熱性が向上して温度変動振幅 $\Delta T_{w}$ が大き くなるが, 周波数が高くなると, 伝熱面の熱容量の影 響で $\Delta T_{w}$ が低下するとともに， $\delta_{a}$ の依存性がなくな る.これは, 周波数が高いと薄膜のごく近傍でしか空 気層温度が変動しなくなるためである.また, 図 $4(\mathrm{c})$ には伝導板表面の温度変動振幅 $\Delta T_{c}$ も示した. 本計算条件の範囲 $(f>0.05 \mathrm{~Hz})$ では $\Delta T_{c}$ は十分小さ く(伝熱面の温度変動幅の $2 \%$ 以下), 伝導板表面の温 度は定常として扱うことができる。もし低周波数側の $\Delta T_{c}$ を小さくしたければ, 伝導板を厚くして熱容量を
大きくすればよい.

\section{4. 空間 分 解 能}

$4 \cdot 1$ 空間分解能の解析解 次に, 伝熱面内の熱 伝導に起因する空間分解能を調べる，まず，空気層へ の熱伝導, 熱放射が十分小さい場合を考える。簡単の ため, 定常状態でかつ薄膜の温度が $x$ 方向に正弦的に 変化するとする。

$$
T_{w}=\overline{T_{w}}+\Delta T_{w} \sin \left(\frac{2 \pi}{b} x\right)
$$

ここで $b$ は温度分布の波長である。このとき，式(1・ a), (2・a), (4) 上り次式が成り立つ.

$$
h\left(T_{w}-T_{0}\right)=\dot{q}_{c v}=\dot{q}_{i n}+\lambda \delta \frac{d^{2} T_{w}}{d x^{2}}
$$

仮に，薄膜内で熱伝導が起こらないとし，そのときの 薄膜の温度を $T_{w 0}$ とすれば, 式(18) は次式で表され る.

$$
\begin{gathered}
h\left(T_{w 0}-T_{0}\right)=\dot{q}_{c v}=\dot{q}_{i n} \\
\text { 式 }(17) \sim(19) \text { 加 } T_{w 0} \text { を求めると, } \\
T_{w 0}=\overline{T_{w}}+\left[\frac{\lambda \delta}{h}\left(\frac{2 \pi}{b}\right)^{2}+1\right] \Delta T_{w} \sin \left(\frac{2 \pi}{b} x\right)
\end{gathered}
$$

となる.式(17) と式(20)の比較により, 薄膜内の熱伝 導に起因する温度振幅の減衰率 $\xi$ は

$$
\xi=\frac{1}{\frac{\lambda \delta}{h}\left(\frac{2 \pi}{b}\right)^{2}+1}
$$

であることがわかる.温度振幅が $1 / 2$ に減衰 $(\xi=$ $1 / 2)$ する波長 $b$ を空間分解能 $\beta$ と定義すると,

$$
\beta=b_{(\xi=1 / 2)}=2 \pi \sqrt{\frac{\lambda \delta}{h}}
$$

となる。

$4 \cdot 2$ 熱損失を考慮した空間分解能 次に, 熱伝 導, 熱放射を考慮した数值解析を行う.今, 温度測定 面に次式で表される定常な熱伝達率分布があるとす る.

$$
h=\bar{h}+\Delta h \sin \left(\frac{2 \pi}{b} x\right)
$$

この熱伝達率分布を実験的に評価しょうとすれば，簡 単には薄膜表面の温度分布 $T_{w}$ および伝導板の空間平 均温度 $\bar{T}_{c}$ を測定すればよく，このとき，熱伝達率 $h_{s 1}$ は次式で評価することができる。

$$
h_{s 1}=\frac{\dot{q}_{i n}-\dot{q}_{c d}^{\prime}-\dot{q}_{r d}-\dot{q}_{r d i}^{\prime}}{T_{w}-T_{0}}
$$

また，赤外線計測の空間分解能が十分小さければ，薄 膜の熱伝導に起因する空間的減衰を次式のように補正 することができる. 


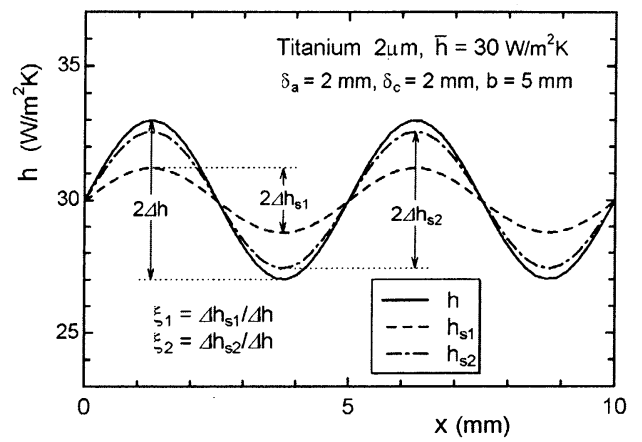

Fig. 5 Distribution of an original and estimated heat transfer coefficients; Ti foil, $\delta=2 \mu \mathrm{m}, \bar{h}=30$ $\mathrm{W} /\left(\mathrm{m}^{2} \cdot \mathrm{K}\right), b=5 \mathrm{~mm}$

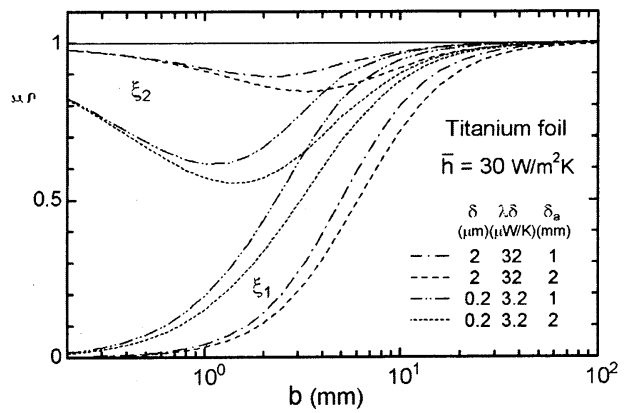

(a) attenuation rate of spatial amplitude, $\xi$

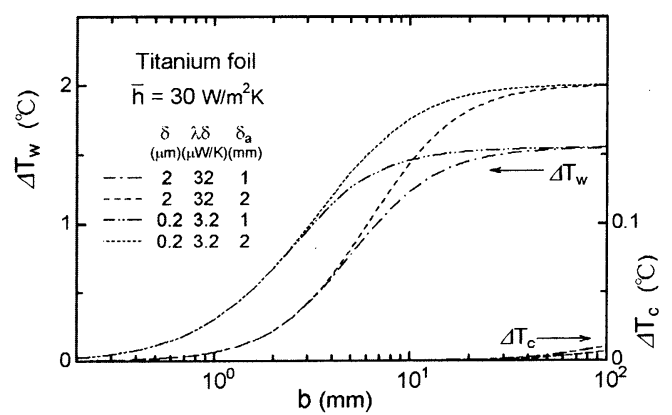

(b) amplitude of temperature distribution; $\Delta T_{w}$ and $\Delta T_{c}$

Fig. 6 Spatial attenuation; Ti foil, $\delta=2 \mu \mathrm{m}, \quad \bar{h}=30$ $\mathrm{W} /\left(\mathrm{m}^{2} \cdot \mathrm{K}\right)$

$$
h_{s 2}=\frac{\dot{q}_{i n}-\dot{q}_{c d}^{\prime}-\dot{q}_{r d}-\dot{q}_{r d i}^{\prime}+\lambda \delta \frac{d^{2} T_{w}}{d x^{2}}}{T_{w}-T_{0}}
$$

式(24)および式(25)から評価される熱伝達率 $h_{s 1}$, $h_{s 2}$ と, 式(23)で与えた真の熱伝達率 $h$ の差異を, 二 次元解析により調べた。図 5 に, 熱伝達率分布の一例 (チタンはく, $\delta=2 \mu \mathrm{m}, \bar{h}=30 \mathrm{~W} /\left(\mathrm{m}^{2} \cdot \mathrm{K}\right), \quad b=5$ $\mathrm{mm})$ を示す. $h_{s 1}$ の振幅は大きく減衰しているが, 薄 膜内の熱伝導の影響を補正した $h_{s 2}$ の減衰は抑えら
れ, 真の值 $h$ に近づいている.ここで, 空間的振幅の 減衰率を $\xi\left(\xi_{1}=\Delta h_{s 1} / \Delta h, \xi_{2}=\Delta h_{s 2} / \Delta h\right)$ と定義する。

図 $6 に$, チタンはく $[\delta=2,0.2 \mu \mathrm{m}, \lambda=16 \mathrm{~W} /(\mathrm{m} \cdot \mathrm{K})]$ の空間特性を示す。図 $6(\mathrm{a})$ に振幅の減衰率 $\xi$ 示 す。計算条件は周波数応答(図 4)の場合と同じであ る. 式 (24)で見積もった熱伝達率 $h_{s 1}$ は, 空間スケー ル (波長 $b)$ が小さくなるとともに減衰が大きく $\left(\xi_{1}\right.$ が 小さく)なる．また減衰は， $\lambda \delta$ の低下とともに短波長 側にシフトする.さらに, 空気層が厚いほど減衰が大 きくなる、これは後述 $(5 \cdot 3$ 節) のように, 伝熱面の実 効的な熱伝導が増加するためである. 薄膜の $\lambda \delta$ の值 が小さいほどこの影響が大きくなる。一方, 薄膜の熱 伝導を補正した場合 $\left(\xi_{2}\right)$ は，空間スケールが小さくて も減衰が抑えられている，ただし，薄膜だけでなく空 気層にも温度分布が存在するため, 式(25)のように薄 膜内の熱伝導を補正しただけでは完全には熱伝達率の 空間分布を復元することはできない. 完全に復元する ためには, 空気層まで含めた熱伝導の逆問題を解く必 要がある.

図 6(b)に, 温度分布の振幅 $\Delta T_{w}$ を示す. 波長 $b$ が大きいときは空気層厚さ $\delta_{a}$ が大きいほど断熱性が 向上して振幅 $\Delta T_{w}$ が大きくなるが, 波長が小さくな ると伝熱面の熱伝導の影響で $\Delta T_{w}$ が低下するととも に $\delta_{a}$ の依存性がなくなる.これは, 空間スケールが 小さいと薄膜のごく近傍でしか温度分布をもたなくな るためである。また，図 6(b)には伝導板表面の温度 振幅 $\Delta T_{c}$ も同時に示した. 本計算条件の範囲 $(b<$ $100 \mathrm{~mm}$ ) では $\Delta T_{c}$ は十分小さく(伝熱面の温度振幅の $1 \%$ 以下), 伝導板表面の温度は一様として扱うことが できる。

\section{5. 測定可能な時間・空間スケール}

本手法による測定は, 伝熱面温度の時空間的変動幅 が赤外線計測の雑音等価温度差よりも大きいことが必 要条件となる.そのため, ここでは図 4(c)の周波数 特性, 図 6(b) の空間特性を一般化し, 本手法で測定 可能な時間・空間分解能の限界について検討する.

$5 \cdot 1$ 周波数特性の一般化 薄膜の温度が次式の ように正弦的に変動する場合を考える.

$$
T_{w}=\bar{T}_{c}+\Delta T_{w} \sin (\omega t)
$$

このとき, 空気層内では次式で表される温度分布をも ${ }^{(8)}$.

$$
\begin{gathered}
T=\bar{T}_{c}+\Delta T_{w} A \sin (\omega t+\phi) \\
A=\left|\frac{\sinh k_{a} y(1+i)}{\sinh k_{a} \delta_{a}(1+i)}\right|,
\end{gathered}
$$




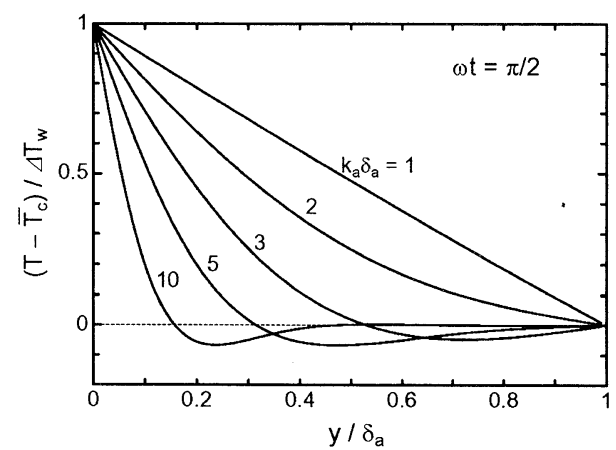

Fig. 7 Temperature distribution in an air layer ; $\omega t=$ $\pi / 2$

$$
\begin{aligned}
& \phi=\arg \left\{\frac{\sinh k_{a} y(1+i)}{\sinh k_{a} \delta_{a}(1+i)}\right\} \\
& k_{a}=\sqrt{\frac{\omega}{2 \alpha_{a}}}
\end{aligned}
$$

ここで, || は複素数の絶対值, $\arg \{\}$ は複素数の偏角 である.また， $\alpha_{a}$ は空気の温度伝導率 $\left(=\lambda_{a} / c_{a} \rho_{a}\right)$ で ある.図 7 に, 空気層内の厚さ方向の瞬間温度分布 $\left(\omega t=\pi / 2\right.$ の場合)を示す. 温度分布の形状は $k_{a} \delta_{a}$ の 值で決まり，周波数が低い場合 $\left(k_{a} \delta_{a}<1\right)$ は分布は線 形で近似できるが，周波数が高い場合 $\left(k_{a} \delta_{a} \gg 1\right)$ は薄 膜の近傍 $\left(y / \delta_{a}<1 / k_{a} \delta_{a}\right)$ でしか温度変動が起こらな い. なお, $k_{a} \delta_{a} \geq 3$ では空気層内の振動が不足減衰と なるため, 温度分布に振動が現れる.ここで, 薄膜と ともに温度変動する実効的な空気層厚さ $\left(\delta_{a}^{*}\right)_{f}$ は次式 で近似される。

$$
\begin{aligned}
& \left(\delta_{a}^{*}\right)_{f} \approx 0.5 \delta_{a}, \quad\left(k_{a} \delta_{a}<1\right) \cdots \\
& \left(\delta_{a}^{*}\right)_{f} \approx 0.5 / k_{a},\left(k_{a} \delta_{a}>1\right)
\end{aligned}
$$

この $\left(\delta_{a}^{*}\right)_{f}$ 内の空気の熱容量が時間遅れの原因となる ため, 伝熱面の時定数は, 空気層の影響を含めると次 式で近似できる。

$$
\begin{aligned}
\tau^{*} & \approx \frac{c \rho \delta+c_{a} \rho_{a}\left(\delta_{a}^{*}\right)_{f}}{h_{t}} \\
h_{t} & =\frac{\dot{q}_{i n}}{T_{w}-T_{0}} \quad \ldots \ldots . .
\end{aligned}
$$

$h_{t}$ は, 対流熱伝達に伝導や放射伝熱も加えた全熱伝 達率である。このとき，カットオフ周波数は次式で定 義される。

$$
f_{c}^{*}=\frac{1}{2 \pi \tau^{*}}
$$

次に, 無次元周波数 $\tilde{f}$ と無次元温度変動 $\left(\Delta \tilde{T}_{w}\right)_{f}$ を 導入する.

$$
\tilde{f}=f / \overline{f_{c}^{*}} \text {. }
$$

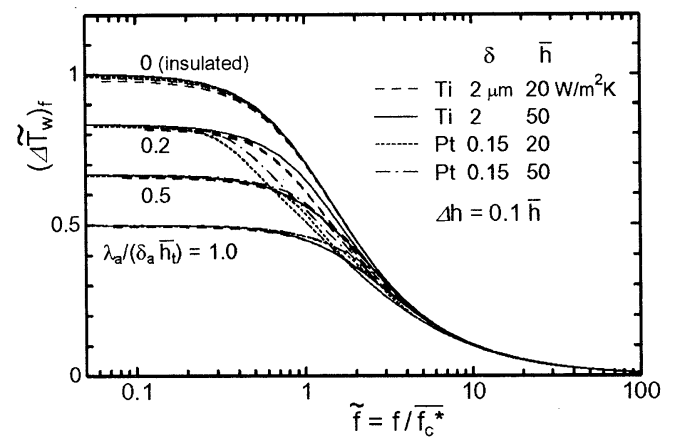

Fig. 8 Relation of non-dimensional temperature fluctuation $\left(\Delta \tilde{T}_{w}\right)_{f}$ against non-dimensional frequency $\tilde{f}$

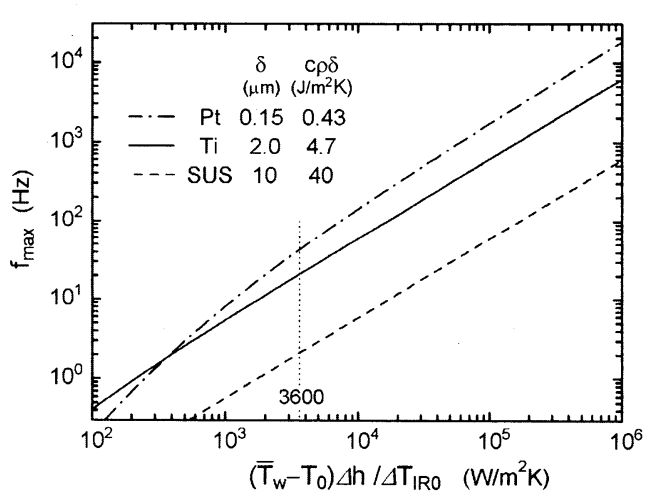

Fig. 9 Upper limit of frequencies detectable using infrared measurement

$$
\left(\Delta \widetilde{T}_{w}\right)_{f}=\frac{\Delta T_{w} \overline{h_{t}}}{\overline{T_{w}}-T_{0}}
$$

周波数 $f$ が十分低く，熱放射抢よび熱伝達変動 $\Delta h / \bar{h}$ が十分小さいとすると, 式(1・a)，(2・a)，(4)，(14) から $\left(\Delta \tilde{T}_{w}\right)_{f}=1 /\left[1+\lambda_{a} /\left(\delta_{a} \bar{h}\right)\right]$ が導出される.つま り, $\lambda_{a} /\left(\delta_{a} \bar{h}\right)$ の值が大きくなると空気層への熱伝導の 影響が大きくなり，温度変動幅が低下する.

図 8 に, $\tilde{f}$ と $\left(\Delta \tilde{T}_{w}\right)_{f}$ の関係を示す。ここでは, チ タンはく $(\delta=2 \mu \mathrm{m})$ および白金はく $(\delta=0.15 \mu \mathrm{m})$ に ついて, $\bar{h}=20,50 \mathrm{~W} /\left(\mathrm{m}^{2} \cdot \mathrm{K}\right), \Delta h=0.1 \bar{h}, \overline{T_{w}}-T_{0}$ $=10,30^{\circ} \mathrm{C}, T_{0}=20^{\circ} \mathrm{C}, \lambda_{a} /\left(\delta_{a} \overline{h_{t}}\right)=0,0.2,0.5,1.0$ として周波数特性を計算し, 各パラメータの依存性を 調べた。なお，ここでは熱放射の影響を考慮するため， $\lambda_{a} /\left(\delta_{a} \bar{h}\right)$ の代わりに $\lambda_{a} /\left(\delta_{a} \overline{h_{t}}\right)$ を用いている.

低周波数 $(\tilde{f} \leq 0.1)$ では, $\left(\Delta \widetilde{T}_{w}\right)_{f}$ は $\tilde{f}$ に依存せず一 定値となる。

$$
\left(\Delta \widetilde{T}_{w}\right)_{f} \approx \frac{1}{1+\lambda_{a} /\left(\delta_{a} \overline{h_{t}}\right)},(\tilde{f} \leq 0.1)
$$

また周波数が高い $(\tilde{f} \geq 10)$ 場合は, $\tilde{f}$ と $\Delta \tilde{T}_{w}$ の関係 
は薄膜の種類や熱伝達率等の条件に依存しなくなり, 次式で近似される。

$$
\left(\Delta \widetilde{T}_{w}\right)_{f} \approx \frac{1}{\tilde{f}},(\tilde{f} \geq 10)
$$

$\mathbf{5} \cdot 2$ 測定可能な周波数の上限 式 $(28 \cdot b) ，(29)$ 〜 (33), (35)より, 温度変動幅 $\Delta T_{w}$ は, 周波数が十分 高いときには次式で一般化される.

$$
\begin{aligned}
& \Delta T_{w} \approx \frac{\left(\overline{T_{w}}-T_{0}\right) \Delta h}{2 \pi c \rho \delta f+\sqrt{\pi c_{a} \rho_{a} \lambda_{a}} f^{0.5}}, \\
&\left(\tilde{f} \geq 10 \text { and } k_{a} \delta_{a}>1\right) \quad \cdots \cdots . .
\end{aligned}
$$

また赤外線計測の雑音等価温度差 $\Delta T_{I R}$ は次式で表さ れる。

$$
\Delta T_{I R}=\Delta T_{I R 0} / \varepsilon_{I R}
$$

$\Delta T_{I R 0}$ は黒体の場合の雑音等価温度差であり， $\varepsilon_{I R}$ は 被測定面の赤外線計測の波長带域における分光放射率 である，温度変動を検知するためには $\Delta T_{w}>\Delta T_{I R}$ で ある必要があり，式(36)，(37)から次式が導かれる.

$$
\begin{aligned}
& f<\left(\frac{-B+\sqrt{B^{2}-4 A C}}{2 A}\right)^{2} \\
& A=2 \pi c \rho \delta, B=\sqrt{\pi c_{a} \rho_{a} \lambda_{a}}, \\
& C=-\left(\overline{T_{w}}-T_{0}\right) \Delta h \frac{\varepsilon_{I R}}{\Delta T_{I R 0}}
\end{aligned}
$$

つまり，上式の周波数の上限が測定限界 $f_{\max }$ となる.

図 9 に, 3 種類の金属はく(白金はく $\delta=0.15 \mu \mathrm{m}$, $\varepsilon_{I R}=0.05$; チタンはく $\delta=2 \mu \mathrm{m}, \varepsilon_{I R}=0.183$; ステン レスはく $\left.\delta=10 \mu \mathrm{m}, \varepsilon_{I R}=0.15\right)$ の周波数の上限值 $f_{\max }$ を示す.なお，各金属はくの分光放射率 $\varepsilon_{I R}$ は, 著者が赤外線カメラ(TVS 8502, Avio) を用いて評価 した值である。各薄膜の $f_{\max }$ の值は, $\left(\overline{T_{w}}\right.$ - $\left.T_{0}\right) \Delta h / \Delta T_{I R 0}$ の值によって一意に決まり，ほぼ $\left(\overline{T_{w}}\right.$ $\left.-T_{0}\right) \Delta h / \Delta T_{I R 0}$ に比例して上昇する. 仮に, 文献 (7) の平板乱流境界層の測定を想定して, $\left(\overline{T_{w}}-T_{0}\right)=$ $30^{\circ} \mathrm{C}, \overline{h_{t}}=30 \mathrm{~W} /\left(\mathrm{m}^{2} \cdot \mathrm{K}\right), \Delta h / \overline{h_{t}}=0.1, \Delta T_{I R 0}=$ $0.025^{\circ} \mathrm{C}$ をると, $\left(\overline{T_{w}}-T_{0}\right) \Delta h / \Delta T_{I R 0}$ の值は 3600 と なり，この場合，白金はく，チタンはく，ステンレスは くの周波数の上限は，それぞれ $f_{\max }=43,21,2.1 \mathrm{~Hz}$ となる。なお, $\left(\overline{T_{w}}-T_{0}\right) \Delta h / \Delta T_{I R 0}$ の值が小さい場合 は空気層の影響が大きくなり， $f_{\max }$ の低下が著しくな る.この傾向は, 薄膜の熱容量 $c \rho \delta$ が小さいほど顕著 になる。

$5 \cdot 3$ 空間スケール特性の一般化 薄膜の $x$ 方向 に，定常的な温度分布がある場合を考える.

$$
T_{w}=\bar{T}_{c}+\Delta T_{w} \sin \left(\frac{2 \pi}{b} x\right)
$$

このとき, 空気層内では次式で表される温度分布をも $\supset^{(8)}$.

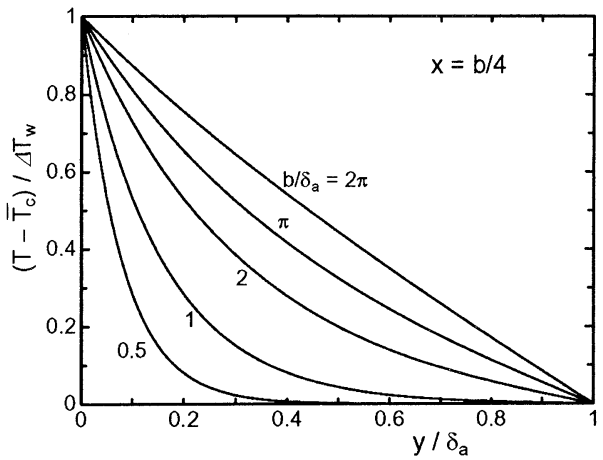

Fig. 10 Temperature distribution in an air layer ; $x=$ b/4

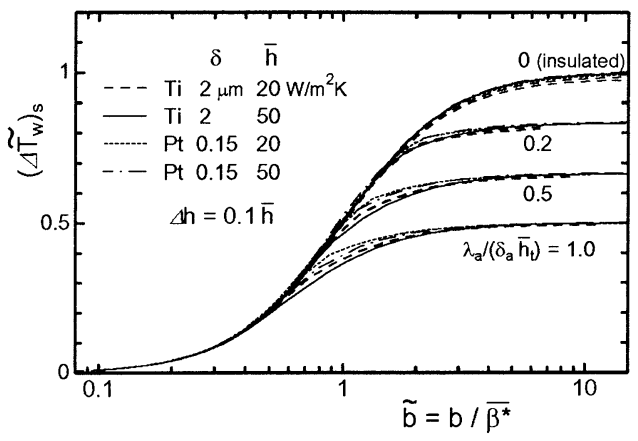

Fig. 11 Relation of non-dimensional amplitude in space $\left(\Delta \tilde{T}_{w}\right)_{s}$ against non-dimensional wavelength $\tilde{b}$

$$
\begin{aligned}
T & =\bar{T}_{c} \\
& +\Delta T_{w} \sin \left(\frac{2 \pi}{b} x\right) \sinh \left[\frac{2 \pi}{b}\left(\delta_{a}-y\right)\right] \\
& \times \operatorname{cosech}\left(\frac{2 \pi}{b} \delta_{a}\right) \ldots \ldots \ldots \ldots \ldots \ldots \ldots \ldots \ldots \ldots \ldots \ldots \ldots \ldots \ldots
\end{aligned}
$$

空気層内の厚さ方向の温度分布 $(x=b / 4$ の場合)を図 10 に示す．温度分布の形状は $b / \delta_{a}$ の值で決まり，波 長が長い場合 $\left(b / \delta_{a}>2 \pi\right)$ は分布は線形で近似できる が，波長が短い場合 $\left(b / \delta_{a} \ll 2 \pi\right)$ は指数関数に近づく. ここで, 薄膜の温度分布の影響を受ける実効的な空気 層厚さ $\left(\delta_{a}^{*}\right)_{s}$ は次式で近似される。

$$
\begin{aligned}
& \left(\delta_{a}^{*}\right)_{s} \approx \delta_{a},\left(b / \delta_{a}>2 \pi\right) \cdots \cdots \cdots \cdots \cdots \cdots \cdots \cdots \cdots(41 \cdot a) \\
& \left(\delta_{a}^{*}\right)_{s} \approx b / 2 \pi,\left(b / \delta_{a}<2 \pi\right)
\end{aligned}
$$

この $\left(\delta_{a}^{*}\right)_{s}$ 内の熱伝導が空間的減衰の原因となるた め, 伝熱面の空間分解能は, 空気層の影響を含めると 次式で近似できる。

$$
\beta^{*}=2 \pi \sqrt{\frac{\lambda \delta+\lambda_{a}\left(\delta_{a}^{*}\right)_{s}}{h_{t}}}
$$

次に, 無次元波長 $\tilde{b}$ と無次元温度振幅 $\left(\Delta \tilde{T}_{w}\right)_{s}$ を導 入する。 


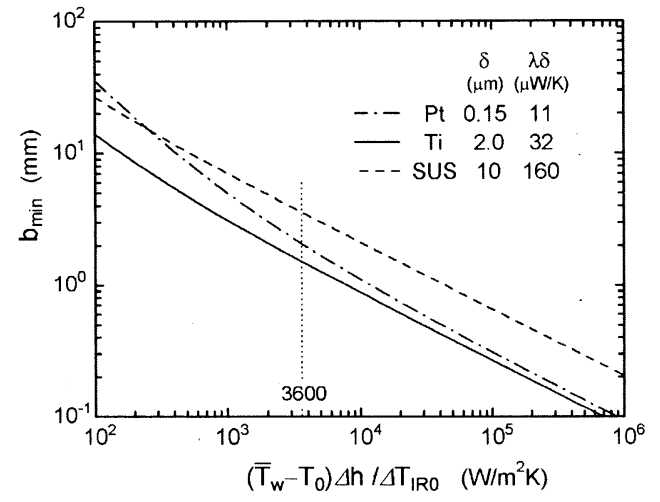

Fig. 12 Lower limit of spatial wavelength detectable using infrared measurement

$$
\begin{aligned}
& \tilde{b}=b / \overline{\beta^{*}} \ldots \ldots \ldots \ldots \ldots \ldots \ldots \\
& \left(\Delta \tilde{T}_{w}\right)_{s}=\frac{\Delta T_{w}}{\overline{T_{w}}-T_{0}} \frac{\overline{h_{t}}}{\Delta h}
\end{aligned}
$$

図 11 に, $\tilde{b}$ と $\left(\Delta \widetilde{T}_{w}\right)_{s}$ の関係を示す. 計算条件は周波 数応答 (図 8)の場合と同じである. 空間スケールが大 きい場合 $(\tilde{b} \geq 10)$ は, $\left(\Delta \tilde{T}_{w}\right)_{s}$ は $\tilde{b}$ に依存せず一定值と なる.

$$
\left(\Delta \tilde{T}_{w}\right)_{s} \approx \frac{1}{1+\lambda_{a} /\left(\delta_{a} \overline{h_{t}}\right)},(\tilde{b} \geq 10)
$$

また, 空間スケールが小さい場合 $(\tilde{b} \leq 0.3)$ は, $\tilde{b}$ と $\left(\Delta \tilde{T}_{w}\right)_{s}$ の関係は薄膜の種類や熱伝達率等の条件に依 存しなくなり, 次式で近似できる.

$$
\left(\Delta \widetilde{T}_{w}\right)_{s} \approx \tilde{b}^{2},(\tilde{b} \leq 0.3)
$$

$\mathbf{5 \bullet 4}$ 測定可能な空間スケールの下限 式 $(41 \cdot b)$, (42) （44）, (46)より, 空間的な温度振幅 $\Delta T_{w}$ は, 波 長が十分短いときには次式で一般化される。

$$
\begin{aligned}
& \Delta T_{w} \approx \frac{\left(\overline{T_{w}}-T_{0}\right) \Delta h}{4 \pi^{2} \lambda \delta b^{-2}+2 \pi \lambda_{a} b^{-1}}, \\
&\left(\tilde{b} \leq 0.3 \text { and } b / \delta_{a}<2 \pi\right)
\end{aligned}
$$

この振幅を検知するためには $\Delta T_{w}>\Delta T_{I R}$ である必要 があり, 式(37), (47)から次式が導かれる.

$$
\begin{aligned}
& b>\frac{2 A^{\prime}}{-B^{\prime}+\sqrt{B^{\prime 2}-4 A^{\prime} C^{\prime}}} \\
& A^{\prime}=4 \pi^{2} \lambda \delta, B^{\prime}=2 \pi \lambda_{a}, \\
& C^{\prime}=-\left(\overline{T_{w}}-T_{0}\right) \Delta h \frac{\varepsilon_{I R}}{\Delta T_{I R 0}}
\end{aligned}
$$

つまり，上式の波長の下限が測定限界 $b_{\min }$ となる.

図 12 に, 3 種類の金属はくについて波長の下限値 $b_{\min }$ を示す. 各金属はくの $b_{\min }$ の值は, $f_{\max }$ の場合と 同様に $\left(\overline{T_{w}}-T_{0}\right) \Delta h / \Delta T_{I R 0}$ の值によって一意に決ま り,ほほ $\left(\overline{T_{w}}-T_{0}\right) \Delta h / \Delta T_{I R 0}$ の值の $1 / 2$ 乗に反比例し
て低下する. 仮に, $\left(\overline{T_{w}}-T_{0}\right) \Delta h / \Delta T_{I R 0}$ の值が 3600 であるとすると, 白金はく, チタンはく, ステンレス はくの場合の波長の下限は，それぞれ $b_{\min }=2.1,1.5$, $3.6 \mathrm{~mm}$ となる。なお, $\left(\overline{T_{w}}-T_{0}\right) \Delta h / \Delta T_{I R 0}$ の值が小 さい場合には空気層の影響が大きくなり, $b_{\min }$ の増加 が著しくなる，この傾向は, 薄膜の $\lambda \delta$ の值が小さい ほど顕著になる。また，白金はくの $\lambda \delta$ の值はチタン はくの $1 / 3$ 程度であるが, 分光放射率の值がチタンは くの $1 / 3$ 以下であるため, $b_{\min }$ の值はチタンはくを上 回る.

なお, 本解析では現象を単純化するため, 時間変動 と空間分布は別々に扱い, また, 空間分布は一次元的 であるとした.しかし，一般に対流熱伝達には時間変 動と空間分布が共存し，しかも二次元的な空間分布を もつため, $f_{\max }$ および $b_{\min }$ の值は本解析結果より悪化 することが予想される. また, 式(16), (25)や逆問題 の解析により熱伝達率を復元する場合には, 赤外線計 測に伴う雑音の周波数・空間特性が影響するため, 復 元できる周波数の上限抢よび空間波長の下限は, 本解 析で求めた $f_{\max }$ および $b_{\min }$ とは一致しない.ただし, 本解析で得られた結果は, 測定結果の有意性を検討す るうえで, また熱伝達率の復元が可能かどうかを検討 するうえで有効な指標となるとともに, 測定でどのよ うな薄膜および赤外線カメラを選択すべきかを検討す るうえで役に立つ。

\section{6. 結 論}

赤外線カメラを用いて対流熱伝達の時空間分布を測 定することを想定し, 導電性薄膜 (金属はく)で構成さ れた伝熱面からの熱伝達の周波数応答および空間分解 能を解析的に調べた。

（1）熱伝導・熱放射損失が小さい場合，時定数 $\tau$ および空間分解能 $\beta$ は次式で表される.

$$
\tau=\frac{c \rho \delta}{h}, \beta=2 \pi \sqrt{\frac{\lambda \delta}{h}}
$$

（2）薄膜の裏側に空気層を設けて断熱した場合, 空気層が厚いほど断熱性が向上して温度の時間的・空 間的振幅が大きくなる.しかし同時に, 空気層内の温 度変動・温度分布の影響で伝熱面の実効的な熱容量・ 熱伝導が大きくなり, 測定の時定数・空間分解能は悪 化する。

（3）空気層の影響を含めると, 時定数 $\tau^{*}$ は次式 で近似される。

$$
\begin{aligned}
\tau^{*} & \approx \frac{c \rho \delta+c_{a} \rho_{a}\left(\delta_{a}^{*}\right)_{f}}{h_{t}} \\
& \left(\delta_{a}^{*}\right)_{f} \approx 0.5 \delta_{a},\left(k_{a} \delta_{a}<1\right)
\end{aligned}
$$


$\left(\delta_{a}^{*}\right)_{f} \approx 0.5 / k_{a},\left(k_{a} \delta_{a}>1\right)$

また, 空間分解能 $\beta^{*}$ は次式で近似される.

$$
\begin{gathered}
\beta^{*}=2 \pi \sqrt{\frac{\lambda \delta+\lambda_{a}\left(\delta_{a}^{*}\right)_{s}}{h_{t}}} \\
\left(\delta_{a}^{*}\right)_{s} \approx \delta_{a},\left(b / \delta_{a}>2 \pi\right) \\
\left(\delta_{a}^{*}\right)_{s} \approx b / 2 \pi,\left(b / \delta_{a}<2 \pi\right)
\end{gathered}
$$

(4) 測定可能な周波数の上限 $f_{\text {max }}$ および空間波 長の下限 $b_{\min }$ は, 伝熱面の種類および $\left(\overline{T_{w}}\right.$ - $\left.T_{0}\right) \Delta h / \Delta T_{I R 0}$ の值によって一意に決まる.

\section{文献}

(1) Simonich, J. C. and Moffat, R. J., New Technique for Mapping Heat-Transfer Coefficient Contours, Rev. Sci. Instrum., Vol. 53, No. 5 (1982), pp. 678-683.

(2) Iritani, Y., Kasagi, N. and Hirata, M., Heat Transfer Mechanism in the Near-Wall Region of a Turbulent Boundary Layer (in Japanese), Trans. Jpn. Soc. Mech. Eng., Vol. 48, No. 435, B (1982), pp. 2284-2294.

(3) Hetsroni, G. and Rozenblit, R., Heat Transfer to a Liquid-Solid Mixture in a Flume, Int. J. Multiphase Flow, Vol. 20, No. 4 (1994), pp. 671-689.
(4) Oyakawa, K., Miyagi, T., Oshiro, S., Senaha, I., Yaga, M. and Hiwada, M., Study on Time-Spatial Characteristics of Heat Transfer by Visualization of Infrared Images and Dye Flow, Proceeding 9th Int. Symp. on Flow Visualization, (2000), Pap. no. 233.

(5) Nakamura, H. and Igarashi, T., Heat Transfer in Separated Flow behind a Circular Cylinder for Reynolds numbers from 120 to 30000 (2 nd Report, Unsteady and Three-Dimensional Characteristics), Trans. Jpn. Soc. Mech. Eng., Vol. 69, No. 681, B (2003), pp. 1224-1232.

( 6 ) Ochoa, A. D., Baughn, J. W. and Byerley, A. R., A New Technique for Dynamic Heat Transfer Measurements and Flow Visualization Using Liquid Crystal Thermography, Int. J. Heat and Fluid Flow, Vol. 26 (2005), pp. 264-275.

(7) Nakamura, H. and Igarashi, T., Frequency-Response for the Measurement of Unsteady Heat Transfer Using Infrared Thermograph, Proceeding 6th World Conf. on ExHFT, Matsushima, Japan (2005), paper no. 6-b-7.

(8) Carslaw, H. S. and Jaeger, J. C., Conduction of Heat in Solids, (1959), pp. 105-106, 166-167, Oxford University Press. 